\title{
Toxicidade dos Anestésicos Locais: O Debate Continua!
}

Nos últimos 40 anos tivemos algumas vitórias sobre as complicações causadas pelos anestésicos locais, entretanto, parece que ainda estamos longe da resolução do problema. Recentes publicações relatando parada cardíaca em conseqüência do uso da ropivacaína em bloqueios periféricos ${ }^{1,2}$, considerada por muitos isenta de cardiotoxicidade clínica, evidencia que nossas preocupações em relação aos efeitos tóxicos dos anestésicos locais, permanecem vivas. Esse número da Rev Bras Anestesiol contempla estudo experimental $^{3}$ em cães, avaliando a cardiotoxicidade da bupivacaína com excesso enantiomérico (S75-R25) em comparação à bupivacaína racêmica, apresentando piores resultados para o lado cardíaco em comparação a bupivacaína racêmica.

A ropivacaína foi introduzida na prática clínica no início dos anos 1990 como uma possível alternativa segura à bupivacaína. Em 19794 Albright publicou editorial relatando 6 casos, informalmente, onde quase simultaneamente houve convulsão e colapso cardiovascular após injeção intravascular inadvertida de bupivacaína. A reanimação não teve êxito na maioria dos casos e ficou então evidente que, diferentemente da lidocaína, esse novo anestésico local apresentava concentrações plasmáticas necessárias para produzir convulsões muito próximas às necessárias para produzir parada cardíaca. Portanto, apresentando menor margem de segurança. O colapso cardiovascular é conseqüente a graves disritmias ventriculares desproporcionais à potência do fármaco em comparação a outros anestésicos locais.

Como a ropivacaína é composta basicamente do isômero levógiro concluiu-se que a cardiotoxicidade estava mais ligada ao isômero dextrógiro. A partir daí, passou-se ao desenvolvimento da levobupivacaína, anestésico local composto apenas pelo isômero levógiro da bupivacaína. Pode-se observar ${ }^{5}$ comparando-se a bupivacaína, a ropivacaína e a levobupivacaína, toxicidade maior para a bupivacaína, seguida da levobupivacaína e menor para a ropivacaína (Figura 1).

Entretanto, observou-se também que a potência dos anestésicos locais citados apresenta diferenças. A ropivacaína apresentava menor potência que a bupivacaína ${ }^{6}$ e a levobupivacaína potência intermediária. Ou seja, de que adianta ser menos tóxico e causar anestesia clínica de pior qualidade, levando a necessidade de utilização de maiores concentrações do fármaco? Apesar dos aspectos citados serem verdadeiros, a bupivacaína racêmica apresenta maior potencial de desenvolvimento de graves disritmias ventriculares com lenta dissociação dos canais de sódio durante a diástole ventricular?

No artigo publicado nesse número da revista ${ }^{3}$, o anestésico com maior componente levógiro, teoricamente deveria apresentar menor cardiotoxicidade, entretanto, observou-se me- nor depressão miocárdica com a bupivacaína racêmica. Fato intrigante, também, foi o comportamento da pressão venosa central e pressão capilar pulmonar que aumentaram significativamente com a bupivacaína racêmica em comparação a bupivacaína com excesso enantiomérico, apesar da bupivacaína racêmica apresentar menor depressão miocárdica. Outro fato não levantado foi a avaliação do ritmo cardíaco. A injeção intravascular de bupivacaína desenvolve disritmias ventriculares importantes em doses supra-convulsivantes, normalmente o mecanismo de colapso cardiovascular.

$\mathrm{Na}$ atualidade, parece que o maior risco de toxicidade sistêmica com anestésicos locais não seja conseqüente à anestesia peridural em cirurgias gerais ou em obstetrícia. Os bloqueios periféricos representam a maioria dos casos descritos de cárdio e neurotoxicidade ${ }^{2,3}$. O uso criterioso da anestesia peridural, com respeito às doses tóxicas, uso da dose teste, uso de cateter para fracionamento das doses, monitorização do ritmo cardíaco durante a realização do bloqueio, atenção a sinais clínicos de intoxicação e padronização e treinamento das manobras de reanimação cardíaca, levaram a drástica redução dos relatos de toxicidade.

No campo da anestesia obstétrica, além dos cuidados acima citados, podemos acrescentar o fato de que para analgesia do trabalho de parto, se emprega concentrações de anestésicos locais muito reduzidas a uma velocidade de infusão lenta. Paralelamente, nesses últimos 10 anos, principalmente no Brasil, mas também em vários outros países, a prática de anestesia para operações cesarianas também se alterou. Hoje, na maioria dos centros, a raquianestesia passou a ser a técnica de escolha. A dose empregada varia de 10 a $15 \mathrm{mg}$ de bupivacaína hiperbárica a 0,5\%, tornando a possibilidade de injeção intravascular com intoxicação cardíaca ou convulsões muito pouco prováveis. No complexo hospitalar Pró-Matre Paulista - Santa Joana e no Hospital das Clínicas da Universidade de São Paulo quase 100\%

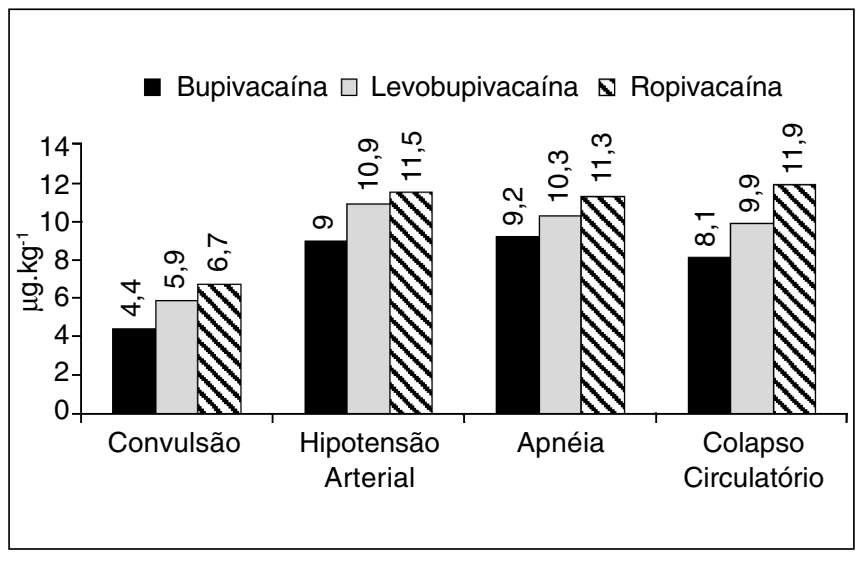

Figura 1 - Efeitos Tóxicos dos Anestésicos Locais 
das operações cesarianas são realizadas com raquianestesia.

Nos bloqueios periféricos parece existir uma tendência à substituição da bupivacaína tradicional pelos anestésicos locais levógiros. A ropivacaína, levobupivacaína e atualmente a bupivacaína com excesso enantiomérico, parecem ter a preferência sobre a bupivacaína racêmica. Apesar disso continuam a serem relatados casos de colapso cardiovascular e convulsões após bloqueios periféricos com esses fármacos. Obviamente, devemos procurar fármacos ideais, mas não devemos nos esquecer que o mecanismo de bloqueio da condução nervosa (bloqueio reversível dos canais de sódio) tão útil na anestesia regional, é também o mecanismo que desencadeia a cardiotoxicidade e as convulsões. Nos bloqueios periféricos, o uso de novas técnicas, para localização precisa dos plexos e nervos, como o estimulador de nervos periféricos, que já é realidade e a ultra-sonografia em fase de introdução na clínica, devem ser cada vez mais utilizados. $O$ uso de cateteres que possibilitem a injeção fracionada de anestésicos locais, apesar das dificuldades técnicas na sua passagem, também pode representar avanços. Não devemos nos esquecer que nos bloqueios periféricos os nervos normalmente correm muito próximos a veias e artérias, e mesmo que não haja uma injeção intravascular inadvertida, a absorção sistêmica pode ser rápida levando a concentrações plasmáticas elevadas dos anestésicos locais. Como sempre foi, e provavelmente sempre será, a diferença está em quem introduz a aguIha. Nós, anestesiologistas não podemos nos contentar em sermos somente exímios "fazedores de bloqueio", devemos também ter conhecimentos científicos atualizados e incorporar cada vez mais novos recursos técnicos à prática clínica diária.

Devemos também considerar a importância da análise crítica ao interpretarmos trabalhos científicos. Um trabalho científico sempre carrega consigo alguma informação. Mas deve ser considerado parte de um todo, na busca do conhecimento global. A informação apresentada nesse número da revista é intrigante ${ }^{3}$. Um anestésico local que carrega em sua fórmula maior componente do isômero levógiro em relação ao dextrógiro, apresentou maior depressão miocárdica que a mistura racêmica. Porém, tal resultado não pode ser analisado de forma matemática. Inúmeras interpretações para o fato podem ser dadas e deve ser reproduzido em outras espécies, com outros métodos para conclusões definitivas.

Unitermos: ANESTÉSICOS, Local: bupivacaína, levobupivacaína, mistura com excesso enantiomérico, ropivacaína; COMPLICAÇÕES: toxicidade sistêmica.

Dr. Marcelo Luís Abramides Torres, TSA

Professor Doutor da Disciplina de Anestesiologia da FMUSP; Coordenador da equipe de Anestesiologia da Maternidade Pró-Matre Paulista; Presidente da LASRA

\section{Toxicity of Local Anesthetics: The Debate Continues!}

In the last 40 years we have won over some of the complications caused by local anesthetics. However, it seems that we are still far from solving them.

Recent reports on cardiac arrests secondary to the use of ropivacaine in peripheral blockade ${ }^{1,2}$, considered by many to be free of clinical cardiotoxicity, demonstrated that our concerns about the toxic effects of local anesthetics are still alive.

This Issue of the Rev Bras Anestesiol presents an experimental study ${ }^{3}$ in dogs that evaluates the cardiotoxicity of excess enantomeric bupivacaine (S75-R25) compared to racemic bupivacaine, showing that the former compound presents worse cardiac effects than the latter.

Ropivacaine was introduced in clinical practice in the beginning of the 1990s as a possible safe alternative to bupivacaine. In $1979^{4}$ Albright published an editorial reporting informally 6 cases in which there were seizures and cardiovascular collapse almost simultaneously after the inadverted intravascular administration of bupivacaine. In most cases, the efforts to reverse the situation were unsuccessful, making it clear that, unlike lidocaine, this new local anesthetic presented plasma concentrations capable to induce seizures that were very close to the plasma concentrations necessary to induce cardiac arrest. Therefore, it presents a narrower safety margin. The cardiovascular collapse is secondary to severe ventricular arrhythmias that are not proportional to the potency of the drug when compared to other local anesthetics. Since ropivacaine is composed basically of the levorotatory isomer, it was concluded that the cardiotoxicity was associated to the dextrorotatory isomer. That is when the development of levobupivacaine, a local anesthetic composed only of the levorotatory isomer of bupivacaine started. Comparing bupivacaine, ropivacaine and levobupivacaine, one can observe $^{5}$ that bupivacaine has the greatest toxicity followed by levobupivacaine, and ropivacaine being the least toxic (Figure 1).

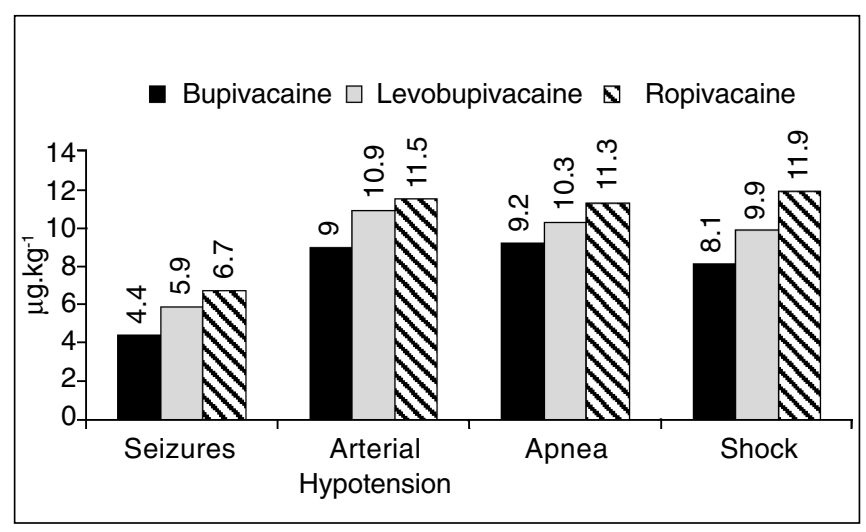

Figure 1 - Toxic Effects of Local Anesthetics 
However, it was observed that the local anesthetics mentioned presented different potencies. Ropivacaine is less potent than bupivacaine ${ }^{6}$, while the potency of levobupivacaine is intermediary. In other words, what is the point of being less toxic and causing less clinical anesthesia if this means that a higher concentration of the drug must be used? Notwithstanding the features mentioned being true, racemic bupivacaine presents the greatest potential to develop severe ventricular arrhythmias with slow dissociation of the sodium channels during ventricular diastole ${ }^{7}$.

In the article published in this issue of the journal ${ }^{3}$, in theory the anesthetic with the greatest levorotatory component should present the least cardiotoxicity; however, it was observed that racemic bupivacaine presented less myocardial depression. It is also intriguing the behavior of the central venous pressure and pulmonary capillary pressure, which increased significantly with racemic bupivacaine when compared to excess enatomeric bupivacaine, despite of the fact that racemic bupivacaine causes less myocardial depression. Another fact that was not studied was the assessment of the cardiac rhythm. The intravascular administration of bupivacaine causes severe ventricular arrhythmias in doses greater than those necessary to cause seizures, which is usually the mechanism of the cardiovascular collapse.

Currently, it seems that the greatest risk of systemic toxicity with local anesthetics is not due to peridural anesthesia in general surgeries or in obstetrics. The peripheral blockades represent the majority of the cases of cardiac and neurological toxicity described ${ }^{2,3}$. The rational use of peridural anesthesia, taking into consideration the toxic doses, use of a test dose, use of a catheter to break down the doses, monitoring the cardiac rhythm during the blockade, attention to clinical signs of intoxication, and the standardization of maneuvers and training personnel on how to conduct resuscitation maneuvers, are responsible for a marked reduction in the toxicity reported.

In the field of obstetric anesthesia, besides the precautions mentioned above, we could add the fact that very small doses of local anesthetics at very slow infusion rates are used for labor analgesia. Concurrently, in the last 10 years, especially in Brazil, but also in other countries, anesthesia for cesareans has also changed. Nowadays, in most centers spinal anesthesia has become the technique of choice. The dose used varies from 10 to $15 \mathrm{mg}$ of $0.5 \%$ hyperbaric bupivacaine, making it possible the use of intravenous administration with a very low probability of cardiac intoxication or seizures. In the hospital complex of Pró-Matre Paulista Santa Joana and in the Hospital das Clínicas da Universidade de São Paulo, almost $100 \%$ of the cesareans are done under spinal anesthesia.

In the peripheral blockades there seems to be a tendency to substitute the traditional bupivacaine by the local levorotatory local anesthetics. Ropivacaine, levobupivacaine, and currently enantomeric excess bupivacaine seem to be preferred over racemic bupivacaine. Nonetheless, cases of cardiovascular collapse and seizures after peripheral blockades with these drugs are still reported. It is obviously that we should look for the ideal drugs but we should not forget that the mechanism of blocking nervous conduction (reversible blockade of sodium channels), which is so useful in regional anesthesia, is also the mechanism that triggers the cardiotoxicity and seizures. In the peripheral blockades the use of new techniques to localize precisely the plexus and nerves, such as the peripheral nerve stimulator, which is a reality, and the ultrasound, currently being introduced for clinical use, should be used more frequently. The use of catheters that make it possible the fractioned administration of local anesthetics, despite the technical difficulties for its introduction, may also represent advancement. We should not forget that on peripheral blockades the nerves usually are located very close to veins and arteries and, even if the drug is not inadvertently administered intravenously, the systemic absorption may be fast, causing high plasma concentrations of the local anesthetics. The difference has always depended, and probably will always depend, on the person introducing the needle. We, anesthesiologists, cannot agree to be just excellent "blockade technicians", we should also possess current scientific knowledge and incorporate new technical resources to the daily clinical practice.

We should also consider the importance of critical analysis when reading scientific reports. A scientific work always presents some information. But it should be considered part of a whole in the search of global knowledge. The information presented in this issue of the journal is intriguing ${ }^{3}$. A local anesthetic whose formula presents a greater amount of the levorotatory isomer than the dextrorotatory one presented greater cardiac depression than the racemic mixture. However, such result cannot be analyzed mathematically. There are several interpretations to explain this fact and it should be reproduced in other species and with other methods to reach definitive conclusions.

Key Words: ANESTHETICS, Local: bupivacaine; enantiomeric excess mixture, levobupivacaine, ropivacaine; COMPLICATIONS: systemic toxicity.

Marcelo Luís Abramides Torres, TSA, M.D. Professor Doutor da Disciplina de Anestesiologia da FMUSP; Coordenador da Equipe de Anestesiologia da Maternidade Pró-Matre Paulista; Presidente da LASRA

\section{REFERÊNCIAS - REFERENCES}

01. Chazalon P, Tourtier JP, Villevieille T et al - Ropivacaine-induced cardiac arrest after peripheral nerve block: successful resuscitation. Anesthesiology, 2003;99:1449-1451.

02. Huet O, Eyrolle LJ, Mazoit JX et al - Cardiac arrest and plasma concentration after injection of ropivacaine for posterior lumbar plexus blockade. Anesthesiology, 2003;99:1451-1453 


\section{EDITORIAL}

03. Udelsman A, Munhoz DC, Silva WA et al - Comparação entre os efeitos hemodinâmicos da intoxicação aguda com bupivacaína racêmica e a mistura com excesso enantiomérico de $50 \%$ (S75-R25). Estudo experimental em cães. Rev Bras Anestesiol, 2006;56:391-401.

04. Albright GA - Cardiac arrest following regional anesthesia with etidocaine and bupivacaine. Anesthesiology, 1979; 51:285-287.

05. Santos AC, DeArmas PI - Systemic toxicity of levopubivacaine, bupivacaine, and ropivacaine during continuous intravenous infusion to nonpregnant and pregnant ewes. Anesthesiology, 2001;95:1256-1264.

06. Polley L, Columb M, Naughton $\mathrm{N}$ et al - Relative analgesic potencies of ropivacaine and bupivacaine for epidural analgesia in labor: Implications for therapeutic indexes. Anesthesiology, 1999;90:944-950.

07. Clarkson CW, Hondeghem LM - Mechanism for bupivacaine depression of cardiac conduction: Fast block of sodium channels during the action potential with slow recovery from block during diastole. Anesthesiology, 1985;62:396-405. 